\title{
Automatikus kézírás-felismertetés Kiss József levelezésén
}

\author{
Szűcs Kata Ágnes \\ Petőfi Irodalmi Múzeum Digitális Bölcsészeti Központ (Budapest) \\ szucs.kata@dbk.pim.hu
}

\begin{abstract}
The digital edition of the József Kiss correspondence is a pilot project of the Centre for Digital Humanities, Petőfi Literary Museum. In addition to the processing of the personal and professional letters of the $19^{\text {th }}$-century writer, poet, and editor of the literary journal A Hét (The Week), the project is to explore the possibilities offered by the Transkribus software.

Handwritten Text Recognition is an emerging field of the digital humanities. The paper will discuss this artificial intelligence-based technology and our experiences in creating a Hungarian model. The best result has a 6,94\% character error rate. Apart from the practical experience gained in testing, the paper discusses the possibilities of implementing HTR in public collections.
\end{abstract}

Keywords:HTR, handwritten textrecognition, Transkribus, correspondence, $19^{\text {th }}$-century literature

\section{Bevezető}

Az alábbi esettanulmány a Petőfi Irodalmi Múzeum Digitális Bölcsészeti Központ Handwritten Text Recognition (HTR), azaz a kézírás-felismertetéssel kapcsolatos eddigi munkáját, és a Transkribus használatát hivatott bemutatni. Rövid elméleti áttekintés után, ismertetem a témában szerzett tapasztalatainkat, milyen eredményeket kaptunk a modellek tanításakor, és hogyan sikerült javítani rajtuk.

A modellépítés alapját a PIM Kézirattárában folyamatos feldolgozás alatt álló Kiss Józseflevelezés képezi. A 493 leltári tételből álló korpusz 1683 darab személyes vagy szakmai levelet jelent, melyeknek címzettje vagy írója Kiss József, a 19-20. század fordulóján élt költő és lapszerkesztő. Az ő nevéhez kötődik $A$ Hét címú hetilap alapítása, mely csomópontot jelentett a kialakulóban lévő polgári értelmiség képviselőinek, mintegy alapot teremtve a későbbi irodalmi folyóirat, a Nyugat számára is. A levelezés kiadása hiánypótló és irodalomtörténeti szempontból is jelentőséggel bír. Emellett lehetőséget ad arra, hogy a digitalizált kéziratok gyűjteményi kezelésére, digitális források kiadására alakítsunk ki alternatívákat.

\section{Automatikus kézírás-felismertetés (HTR)}

A kézírás felismerését célzó technika sokáig együtt fejlődött az OCR-rel (optikai karakterfelismerés), ahol a szkennelt dokumentumok nyomtatott szövege válik gép által olvashatóvá. Az OCR technológiában az egyes karakterek képezik a felismerés 
alapját, melyeket előre megadott mintákkal hasonlít össze. A HTR különálló kutatási területté fejlődött a 2000-es évek óta, a kézírások különbözősége és a feladat számítási komplexitása miatt. ${ }^{1}$

Az egyik fő különbség a két technológia között, hogy a HTR egy szegmentált sor szövegében lévő összes karakter felismerésére fókuszál. ${ }^{2}$ A gépi tanulással támogatott technológia képes a vizuális jegyek elsajátítására (így nem kell külön mintákat létrehozni), a neurális háló segítségével pedig több egymást átfedő szövegsor képéből képes karakter valószínúséget számítani. ${ }^{34}$ Természetesen a HTR technológiát nem csak kézzel írt szövegeken lehet alkalmazni.

\section{Transkribus}

\section{Szegmentálás, szöveg átírása}

Az ingyenesen letölthető és használható szoftver megkönnyíti a kéziratokkal való munkát. Az átírás sorról sorra történik a digitális fakszimile folyamatos jelenlétében. Verziókövető rendszerrel van ellátva a program, tehát minden mentés bármikor visszaállítható. Felhő alapú, ezért a megfelelő elővigyázatosságok mellett egy gyűjteményen egyszerre többen is dolgozhatnak párhuzamosan. Sokrétű címkézési és metaadatolási rendszer van beépítve. A fájlokat többféle kimeneti formátumban lehet exportálni (.pdf, .tei, .docx, txt, .xlsx, .zip, stb.) A Transkribus emellett lehetőséget biztosít az automatikus kézírás-felismertetésre és a kézírást felismerő modell létrehozására is.

Magyar nyelven még nem készült nyilvánosan elérhető modell, így azt a program segítségével kezdtük el építeni. ${ }^{5}$ Ehhez a szkennelt kéziratképeket fel kell tölteni a Transkribus szervereire, majd előállítani egy minimum 5-15000 szót tartalmazó, átírással rendelkező korpuszt. A nyomtatott szövegek esetén kevesebb is elengedő lehet. Az átírást a Transkribuson belül is létre lehet hozni, de meglévő átirat akár utólag is hozzárendelhető a képekhez (Text2Image funkció). ${ }^{6}$

Az átíráshoz a képeket szegmentálni kell. A digitális képfeldolgozásban a szegmentálás egy kép több szegmensre (pixelhalmazokra, más néven képobjektumokra) történő

1 Katuščak Dušan, „Automated Transcription of Handwritten Text: READ and TRANSKRIBUS (An Experiment with Transcribing Letters of Andrej Kmet')", 2019. október 20.

2 Puigcerver Joan, „Are Multidimensional Recurrent Layers Really Necessary for Handwritten Text Recognition?", in 2017 14th IAPR International Conference on Document Analysis and Recognition (ICDAR), 01, 2017, 67-72, https://doi.org/10.1109/ICDAR.2017.20.

3 Dietrich Felix, „OCR vs. HTR or "What Is Al, Actually?"”, READ-COOP (blog), elérés 2021. június 2., https://readcoop.eu/insights/ocr-vs-htr/.

4 Puigcerver Joan, „Are Multidimensional Recurrent Layers Really Necessary for Handwritten Text Recognition?", in 2017 14th IAPR International Conference on Document Analysis and Recognition (ICDAR), 01, 2017, 67-72, https://doi.org/10.1109/ICDAR.2017.20.

5 „Public Models in Transkribus”, READ-COOP, elérés 2021. május 26., https://readcoop.eu/transkribus/public-models/.

6 Vö.: „How To Use Existing Transcriptions to Train a HTR-Model with the TextTolmage-Tool”, READCOOP, elérés 2021. június 7., https://readcoop.eu/transkribus/howto/how-to-use-existingtranscriptions-to-train-a-handwritten-text-recognition-model/. 
felosztásának folyamata, célja a kép ábrázolásának egyszerűsítése. ${ }^{7}$ A folyamat során olyan területekre osztjuk a képet, melyek meghatározott koordináták alapján felismerhetővé teszik a sorok és bekezdések helyzetét a neurális háló számára. Három réteget jelölünk ki a képen poligonok formájában (Text Region, Line és a Base Line). A szegmentálás manuálisan és automatikusan ${ }^{8}$ (ill., a kettőt keverve) is elvégezhető. Míg az előbbi pontosabb, de időigényesebb, az utóbbinál szükség van az utólagos korrekcióra.

A szegmentálás után megkezdődhet a szövegek átírása is, ami ily módon a sorok szintjére lebontva eleve összeköttetésben van a hozzá tartozó képpel.9

A kézírás-felismertetés szempontjából fontos átíráskor a lehető legpontosabb, betű szerinti átírásra törekedni, és a karaktereket következetesen ugyanúgy megadni. ${ }^{10}$ Az Unicode határain belül lehetőség van speciális karakterek beszúrására is.

\section{HTR modell építése}

Az átírással rendelkező képeket két csoportba osztjuk, melynek során egy Training set (TS) és egy Validation set (VS) jön létre. Lehetőség van ezek automatikus válogatására is, ami $2 \%, 5 \%$, vagy $10 \%$ VS-eket hoz létre. A TS a rendelkezésre álló fájlok kb. $90 \%$-át teszi ki.

A program a TS-be került fájlokon mesterséges intelligencia segítségével azonosítja a sorokban látható írásképet az átírt szöveggel. Egy tanulási ciklus (epoch) során végigmegy a TS összes fájlján és vizuális jegyek alapján kitalálja, hogy a szegmentált sorok milyen karakterekből állnak össze. Ezután ellenőrzi magát az általunk megadott átírásra hagyatkozva. A tanulási folyamat több ilyen ciklusból áll össze, és a következő epoch-ba már az előzőből elsajátított tudással kezd bele. Az epoch-ok száma a dokumentumok minősége szerint változtatható (max. 250).

Végül a másik csoporton, a VS-en teszteli le magát a mesterséges intelligencia. Ennél a csoportnál csak a TS-en elsajátítottakra és a képen látható vizuális jegyekre hagyatkozik. A VS-ben lévő fájlokon egyszer megy végig, majd ellenőrzi magát az emberi intelligencia által készített átírás alapján. Az itt kapott hibaérték (CER on Validation set) azt jelzi, hogyan teljesít a modell egy ismeretlen szövegen. Az eredményességet tovább lehet növelni Base Model beépítésével. Ilyenkor egy másik HTR modellből már elsajátított tudást építünk be.

7 Srinivasan G N, „Segmentation Techniques for Target Recognition” 1, 3 (2007): 7.

8 Elforgatott rájegyzések, szokatlan oldaltörések (pl. borítékok, képeslapok) esetében többet téveszt.

9 A Transkribus lehetőséget biztosít a szavak szintjén történő szegmentálásra is, de mivel a funkció használatát egy rövid tesztidőszakot követően elvetettük, a továbbiakban erről nem lesz szó

10 Például egy német szövegnél a sárfesz s-t egyféleképpen, ß karakterrel, vagy dupla s-sel jelöljük, nem keverve. A hiányzó szövegrészeket pedig jobb üresen hagyni. 
Az eddigi legjobb eredményt a KEZ17_Kiss József kézírása_5 nevú modellel sikerült elérni, ahol a CER on Validation Set értéke $6,94 \%$ volt. Ez azt jelenti, hogy a modell által készített átírásban könnyen javítható hibák találhatók (pl. ékezetek, egy-egy betǔtévesztés).

\section{Tapasztalataink}

\subsection{Első fázis}

Egy modell kialakításakor fontos, hogy a korpuszban jobbára egy kéz által írt szövegek legyenek, melyek korban közel keletkeztek egymáshoz, illetve, hogy a forrás típusa is egyező legyen (pl. napló, számadáskönyv, levelezés stb.). ${ }^{11}$ Először létrehoztunk egy csak Kiss József kézírásából és egy mindenki máséból álló korpuszt, ahova folyamatosan kerültek be újabb átírt anyagok a neurális háló számára.

Eleinte kevés kapaszkodót találtunk az eredmények értékelésére. A modellek finomhangolására nézve saját magunknak kellett egy viszonyrendszert kialakítani. Először is felmértük a rendelkezésre álló anyag összetételét. Erre különböző csoportokat alakítottunk ki, felcímkézve és táblázatos formában nyilvántartva a levelek nyelvét, a kézírás eszközét (ceruza vagy toll), illetve, hogy géppel írt vagy nyomtatott a dokumentum. Úgy véltük ezek olyan faktorok, amelyek befolyásolhatják a kézírás-felismertetést végrehajtó neurális háló viselkedését. A gépi feldolgozás során az algoritmus figyelembe veszi az adott nyelvben előkerülő karakterek számát és azok egymáshoz viszonyított előfordulási gyakoriságát is. Másrészt a nyomtatott és géppel írt betűk más vizuális jegyekkel rendelkezek, mint a kézzel írtak.

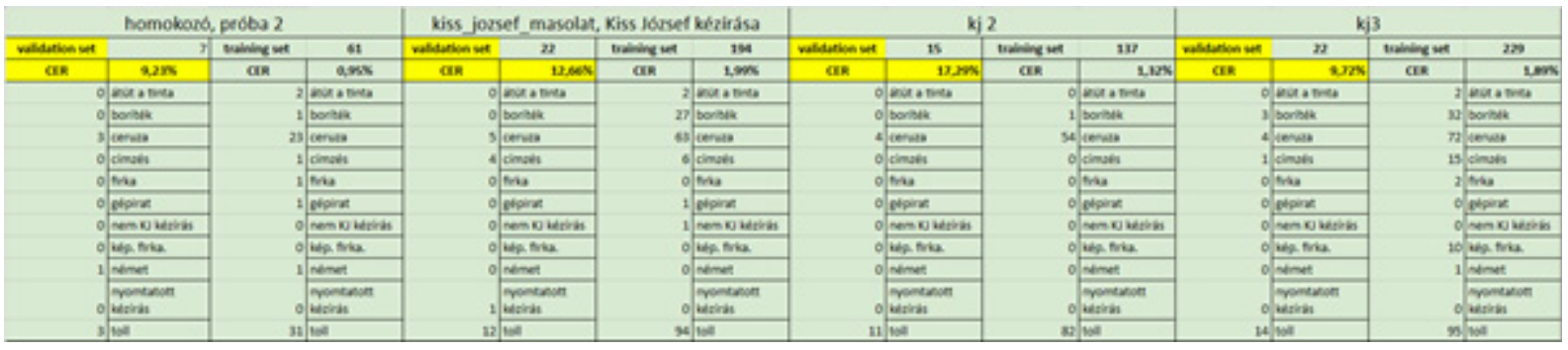

1. ábra Az első modellek

Az első modellépítések eredményei a folyamatosan bővülő szövegkorpusz miatt nem voltak teljes mértékben összehasonlíthatóak, de rengeteg tapasztalatot szereztünk, és kijelölték a további tesztelések irányát.

\subsection{Második fázis}

Ekkorra a Kiss József által írt levelek nagy részét feldolgoztuk, ez kb. 370 felhasználható oldalt, több mint 20.000 szót jelentett. Az elképzelés szerint egyféle anyagon többféleképpen teszteltük a modelleket. 

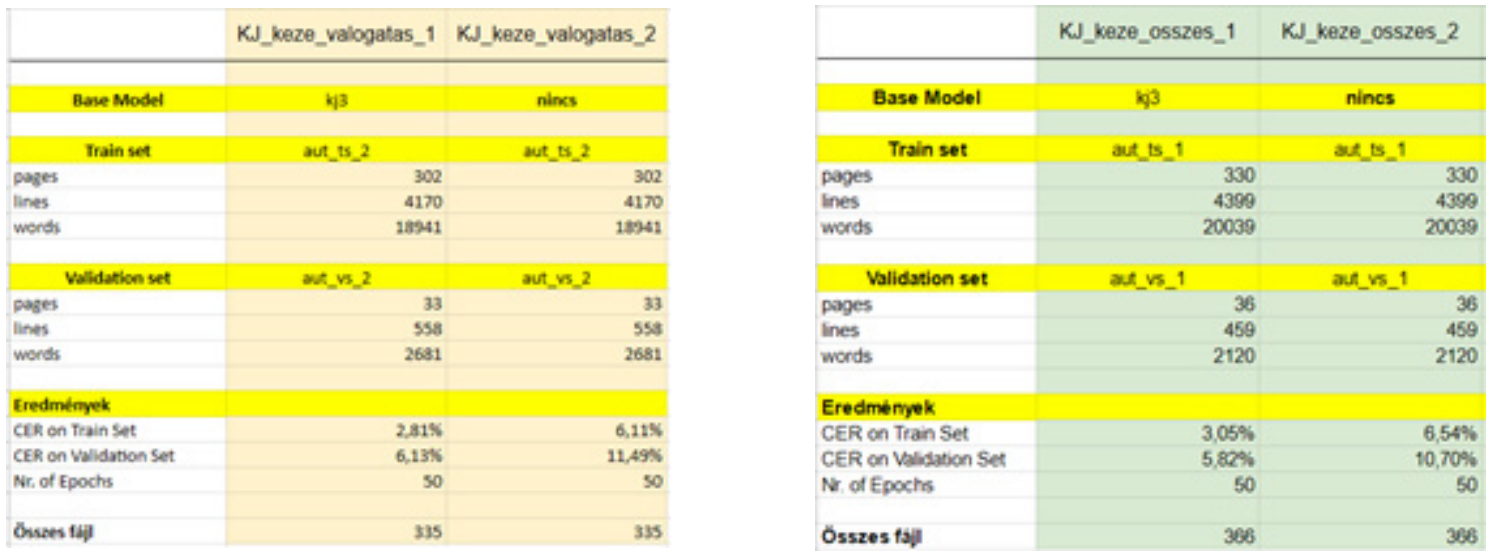

2. ábra A Válogatás gyüjtemény eredményei az Összes gyújteményhez képest

Először megbizonyosodtunk arról, hogy a tollal, ceruzával és nyomtatottan írt Kiss József levelek külön kezelését megszüntethetjük. A Válogatás gyüjteményben csak Kiss József kézzel írt, magyar nyelvű levelei szerepeltek, ezzel párhuzamosan egy másikban az összes általa írt levél. A válogatott gyǔjteményen futtatott modell eredménye nem jobban, hanem 1-2\%-kal rosszabbul teljesített a másikhoz képest (Vö.: 1. ábra CER on Validation Set sorai). A válogatás minősége fontos, mindkét set-nek megfelelően kell reprezentálnia a korpusz egészének összetételét.

\begin{tabular}{|c|c|c|c|c|c|c|c|c|c|c|c|c|c|c|c|c|}
\hline Model name & Selection & Selection ippe & Base model & sum & & $\begin{array}{l}\text { Train Set } \\
\text { (pages) }\end{array}$ & lines & mords & $\begin{array}{l}\text { Validation set } \\
\text { (pages) }\end{array}$ & Ines & moeds & $\begin{array}{r}\text { a } \\
\text { Epoch Se }\end{array}$ & $\begin{array}{l}\text { CER on Train } \\
\text { Set }\end{array}$ & $\begin{array}{l}\text { CCR on } \\
\text { volidation Set }\end{array}$ & $\begin{array}{l}\text { Collection } \\
\text { ID }\end{array}$ & Collection name \\
\hline 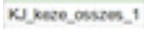 & att & minden atin deds (1OS) & 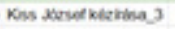 & & 200 & 300 & 4000 & 20000 & $x$ & 650 & 2120 & 50 & $300 \mathrm{~s}$ & 5,000 & $\pi 000$. & Ku_keze_onster_ I \\
\hline KJ_Kere_ossies_2 & sedi & minden ieit dida (100) & mones & & 306 & 300 & 4900 & 20000 & $x$ & 650 & 2120 & 50 & 6.5es & $10,00 \mathrm{~s}$ & noweon & KJ_keze_cossres__ \\
\hline KJ__enze_onsies_3 & manes & $\min a \operatorname{sen}$ an ada & Ku_Keze_onsizes_1 & & 300 & 360 & 4413 & 20014 & 33 & 3 ens & 2284 & 50 & $2.20 \%$ & $4,20 \mathrm{~s}$ & $n 060$ & KJ__enze_onsines_1 \\
\hline Ku_reze_onsin_4 4 & mand & minosen win cadx & Kas sosid keteinha 3 & & 200 & 356 & 4413 & 20014 & 33 & 3 475 & 204 & 50 & $2 \operatorname{sen}$ & 8.305 & $n=00$ & 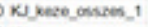 \\
\hline keze_onsen_s & manel & minden utit cads & Ku Kere_onsan_, & & $\infty$ & 20 & 4413 & 2004 & s & 3 ens & 2201 & 100 & $1 \mathrm{~ms}$ & $\cos$ & now & Ku_keze_onsom_, \\
\hline Jere__ossies_6 & ats & minden atit chas (105) & Ku_keve_cossces_t & & 360 & 300 & 4000 & 20000 & $x$ & $6<5$ & 2120 & $\$ 0$ & $2.13 \%$ & $6 \operatorname{sen}$ & now60 & KJ_keze_onster_; \\
\hline
\end{tabular}

\section{3. ábra Második fázisban keletkezett HTR modellek}

Ebben a fázisban a Base Model (BM) használatával is kísérleteztünk, két modell között mindig csak egy dolgot megváltoztatva. A KJ_keze_osszes_4 modellnél az automatikus besorolást felváltotta egy manuális, szélesebb körǔ válogatás. Az eredményeken mégis az látszik, hogy az összes próbálkozás közül ennek a legmagasabb a karakter hiba értéke. Egy másik alapmodellel ugyanez az összeállítás nagyon jó eredményt hozott. Az epoch-ok számát duplázva, a KJ_keze_osszes_5 modellnél szintén rosszabb eredményeket kaptunk. És végül, a hatos modellnél az automatikus TS és VS válogatást alapul véve, egy másik alapmodell szintén rosszabb eredményeket hozott. Ezek alapján az számít, hogy melyik alapmodellt melyik korpuszon használjuk; a legjobb eredményt a hasonló adatokon tanult BM adja.

Az első két esetben a Base Modellel rendelkező modell kb. kétszer jobban teljesített. A többinél azonban már nem ennyire egyértelmú a kimenetel. Ennek oka a BM használatban rejlik. A folyamatos dokumentumfeldolgozás miatt a Base Model és a Training data (VS + TS) között átfedések keletkeztek, ami hamis pozitív eredményt és túltanulást is okozott ezeknél a modelleknél. Tehát, a második fázis legjobb eredményú modellje (4,26\%) egy teljesen új próbaszövegen lefuttatva valójában rosszabbul (8-10\%os pontossággal) teljesített. 


\subsection{Harmadik fázis}

A befolyásoltság (bias) ${ }^{12}$ kizárására a harmadik fázisban került sor. Három, az alábbi ábrán zöld árnyalatokkal jelölt szövegkorpuszt hoztunk létre, és a Base Modell használatát egyelöre megszüntettük, azt a teljes vegyes kézírásmodell tanításakor alkalmazzuk újra.

\begin{tabular}{|c|c|c|c|c|c|c|c|c|c|c|}
\hline & & & & & & & CRR on Validation & in train & & \\
\hline Model name & Selection & Selection type & Train Set & Valldertion set & & tpoch & & & Collection ID & Collection name \\
\hline 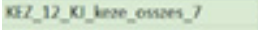 & 6. adag kinteditevel) & manu & 434 & & 48 & zs & $11, n \times$ & $15,09 \%$ & 93264 & 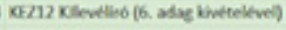 \\
\hline OR 12 Ko bue onves 8 & 6. adag biniteltevel] & manu & 434 & & 48 & so & 8,736 & $6,62 \%$ & 93264 & 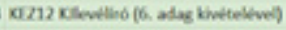 \\
\hline 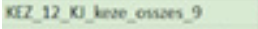 & 6. adag kiviteltevel) & manu & 434 & & 48 & 75 & 8,196 & $4,38 \mathrm{w}$ & 93264 & KEZ12 Kilevether (6. adag bivetelkvel) \\
\hline 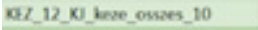 & 6. adag bivitedivel) & manu & 434 & & 48 & 100 & $8,21 \%$ & $3,05 \%$ & 93264 & 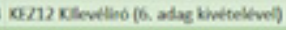 \\
\hline 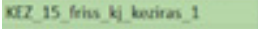 & Wilon testloepuiz & manu & $\$ 06$ & & 42 & 75 & $7,45 \mathrm{~K}$ & $4,35 \%$ & $\$ 5196$ & KEZ15 friss KI Wlak ha modell \\
\hline 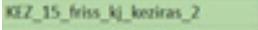 & Rillobn testikepone & manu & 406 & & 42 & 100 & 7,766 & $3,87 \%$ & $\$ \$ 196$ & KEZIS Friss KJ Lavisu medell \\
\hline QR 15 friss $k$ ki beviras 3 & bilon testikepone & wh & tos & & 45 & 75 & $14,19 \%$ & $3,81 \%$ & 55196 & O2Z15 friss KI blokbs modell \\
\hline KEZ 15 friss Xi kesiras 4 & Willon tesriborpunz & m & 405 & & 45 & 75 & $13,81 \mathrm{x}$ & $4,01 \mathrm{x}$ & 95196 & KEZ1S Friss KI Lekhasa modell \\
\hline 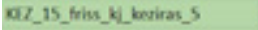 & Bibin testikopuns & an & $\cos$ & & 45 & 75 & $12,16 \%$ & $4,24 \%$ & 55196 & O215 friss KJ Wakbsa modell \\
\hline 072 is trins ki besiras 6 & kilön testikepune & an & $\cos$ & & 45 & 100 & $13,65 \%$ & 2,786 & $\$ 5196$ & KFZ1S friss KJ Leckba modell \\
\hline 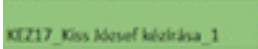 & 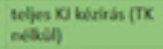 & manu & 455 & & 42 & 75 & $7.30 \%$ & $4,5 \times$ & 95196 & KO215 friss KJ blakbs modell \\
\hline 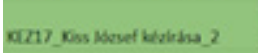 & 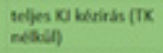 & manu & 455 & & 42 & 100 & $7,15 \%$ & $3,81 \%$ & 55196 & O215 Friss KJ Wlakba medell \\
\hline 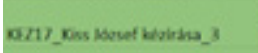 & $\begin{array}{l}\text { teljes } \mathrm{X} \text { blevirbs (TK } \\
\text { celsul) }\end{array}$ & manu & ass & & 42 & 130 & $7,11 \%$ & $2,99 \%$ & $\$ 5196$ & 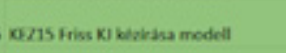 \\
\hline 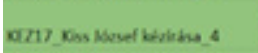 & $\begin{array}{l}\text { Ieljes Ko bivitis (TK } \\
\text { netbil) }\end{array}$ & manu & 455 & & 42 & 150 & $7,01 \%$ & 2,584 & 95196 & 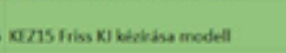 \\
\hline 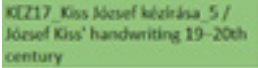 & 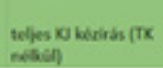 & manu & 45s & & 42 & 200 & 6,946 & $2,13 \times$ & 981 & KFZ15 Friss KI Lechasa modell \\
\hline
\end{tabular}

4. ábra A harmadik fázisban létrehozott HTR modellek

A korpuszokat a szöveg mennyisége és a válogatás folyamata különböztette meg egymástól. Az elsőben (kez_12) a második fázisban alkalmazott felosztást és szövegkorpuszt meghagytuk, de új modellépítés történt (base modell nélkül). A legjobb hibaszázalék-eredmény 8\% körüli lett. A második csoporton belül (kez_15) elkülönítettünk egy tesztkorpuszt, és a fennmaradó anyagból manuálisan alakítottunk ki TS-t és VS-t. A megfelelő mennyiségű epoch után $8 \%$ alá ment a CER értéke. Az automatikus válogatás a második csoporton csak rosszabb eredményeket hozott. A harmadik csoport (kez_17) abban tér el az eddigiektől, hogy az eredeti felosztás mellett a tesztkorpusz anyaga is bekerült a végleges TS-be. Itt értük el a legjobb, 6,94\%-os eredményt, bias nélkül.

\section{Javítási lehetőségek}

Minél több adat áll a neurális háló rendelkezésére, annál jobb eredményt fogunk kapni. Egy bias nélküli Base Model használatával felgyorsul a training process, és kevesebb training data is elég igen jó eredmények eléréséhez. Fontos, hogy a BM szöveganyaga hasonlítson a felismertetésre váró szöveghez, és hogy minden típusú forrás reprezentálva legyen.

Szótárak beépítésével a szövegben előforduló specifikus kifejezéseket lehet megtanítani a MI segítségével, mellyel tovább lehet javítani a modell eredményességén. Ehhez fel kell venni a kapcsolatot a Transkribus csapatával.

12 A statisztikai bias során az eredmények várható értéke eltér a becslés alapjául szolgáló valódi kvantitatív paramétertől. A minta torzított/elfogult, ha nem reprezentatív, ha a vizsgált tulajdonság megoszlása a mintában nem ugyanaz, mint az alapsokaságban. Ennek három oka lehet: (1) a mintavételi eljárás elfogult, (2) a minta elégtelen, (3) túl messzire megy az általánosítás. Margitay Tihamér, Az érvelés mestersége: érvelések elemzése, értékelése és kritikája (Budapest: Typotex, 2007) (11.5. Statisztikus következtetések és hibáik). 
A túltanulás elkerülése végett az epoch-ok számát a tanulási görbe változásának figyelembevételével azon a ponton kell megállítani, ahol az a legalacsonyabban van.

Problémákat okozhat a HTR modell tanulása során a szegmentálás pontatlansága is. Érdemes tehát ellenőrizni, és manuálisan javítani a szegmentálást, figyelembe véve, hogy a rendszer a baseline és a kijelölt sor alapján próbálja megtalálni a szöveges információkat.

A különböző modellek egymásba építésé esetén pedig a TS és VS adatai nem szabad, hogy keveredjenek egymással. Így elkerülhető a fals pozitív eredmény a karakterhibaértékben. ${ }^{13}$

\section{Legújabb eredmények - 6,94\%}
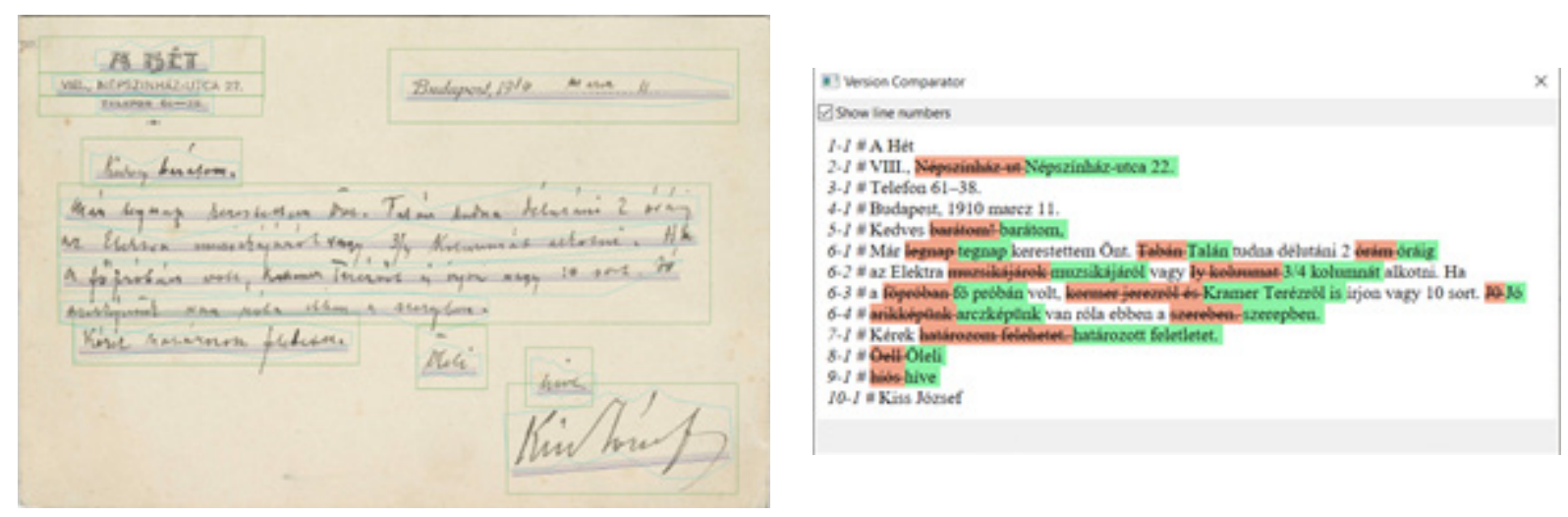

5. ábra A Ground Truth-ként elmentett átírás és a HTR által elvégzett átirat közötti különbségek

A Transkribus-ban összehasonlítható az egyes szövegek különböző verziója. Látható, hogy a 6,94\%-os CER esetében a tévesztések nem értelemzavaróak, többnyire gyorsan javítható ékezetekről, írásjelekről, kis-nagybetű tévesztésről van szó. A későbbiekben az $5 \%$ alatti eredmények elérése a cél.

\section{Következő lépések}

A Transkribus szerves részét képezi a PIM-ben őrzött kéziratos hagyatékok, eddig publikálatlan kéziratok digitális feldolgozása. Ahogy jelenleg az átírást, a jövőben az automatikus kézírás-felismertetést is szeretnénk a workflow részévé tenni. A Kiss Józsefprojekt ideális az igények felmérésére, a fejlesztések és eszközök tesztelésére. Az egyik kimeneti formátum, melyet használunk a kétrétegű PDF. Előnye, hogy a Transkribusból közvetlenül állítható elő és azonnal publikálható a PIM online katalógus felületén (PIM OPAC). ${ }^{14}$ A másik, még tesztelés alatt álló formátum a TEI XML, amely egy következő publikálási stádiumban lesz elérhető. Az átírás végén ez szintén exportálással nyerhető

13 Ha olyan fájlok kerülnek a VS-be, melyeken a mesterséges intelligencia a TS-en tanult, akkor A CER on Validation Set jó százalékos eredményt mutat, de az nem egyezik a modell valós teljesítményével teljesen ismeretlen szövegen.

14 A PIM Kéziratgyűjteményében található Kiss József-levelezés: https://resolver.pim.hu/gyujtemeny/levelek/"Kiss József 1843-1921". 
ki a Transkribusból, viszont megfelelő megjelenítő felület fejlesztése szükséges hozzá, ahol fontos, hogy jól érvényesüljön a szöveg és a fakszimilék sor szintű összeköttetése, $\mathrm{s}$ az átírt szöveget olvasva látszik a kontextus is.

Megkezdődött egy vegyes kézíráson alapuló modell építése. Ezután elérjük azt a szövegmennyiséget, hogy megtörténhet az első magyar nyelvű kézírásmodell publikálása is. Hosszútávon a PIM Kézirattárában lévő egyéb írók kézírásából álló modellek kialakításával, és ezek egymásba építésével egy általánosabb modellt szeretnénk megalkotni, amely a 19-20. századi magyar kézírások automatikus felismertetését teszi majd lehetővé.

\section{Bibliográfia}

Dietrich, Felix. „OCR vs. HTR or “What Is Al, Actually?””. READ-COOP (blog). Elérés 2021. június 2. https://readcoop.eu/insights/ocr-vs-htr/ .

"How To Use Existing Transcriptions to Train a HTR-Model with the TextTolmage-Tool”. READ-COOP. Elérés 2021. június 7. https://readcoop.eu/transkribus/howto/howto-use-existing-transcriptions-to-train-a-handwritten-text-recognition-model/ .

Katuščak, Dušan. „Automated Transcription of Handwritten Text: READ and TRANSKRIBUS (An Experiment with Transcribing Letters of Andrej Kmet')", 2019. október 20.

Margitay, Tihamér. Az érvelés mestersége: érvelések elemzése, értékelése és kritikája. Budapest: Typotex, 2007.

„Public Models in Transkribus”. READ-COOP. Elérés 2021. május 26. https://readcoop.eu/transkribus/public-models/.

Puigcerver, Joan. „Are Multidimensional Recurrent Layers Really Necessary for Handwritten Text Recognition?" In 2017 14th IAPR International Conference on Document Analysis and Recognition (ICDAR), 01:67-72, 2017. https://doi.org/10.1109/ICDAR.2017.20.

Srinivasan, G. N., Shobha, G. "Segmentation Techniques for Target Recognition” INTERNATIONAL JOURNAL OF COMPUTERS AND COMMUNICATIONS, 1, 3 (2007): 75. 